\title{
Experimental analysis of the concrete contribution to shear strength beams without shear reinforcement
}

\section{Análise experimental da contribuição do concreto na resistência ao cisalhamento em vigas sem armadura transversal}
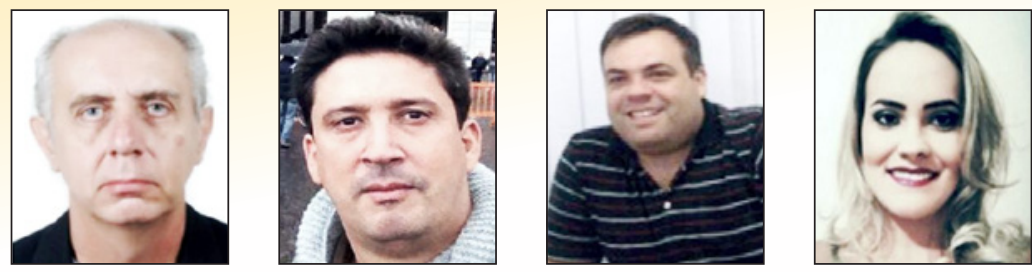

M. S. SAMORA

mssamora@terra.com.br

A. C. DOS SANTOS a acds@feciv.ufu.br

L. M. TRAUTWEIN b leandromt@gmail.com

M. G. MARQUES mariliagmarques@outlook.com

\begin{abstract}
There are many theories and empirical formulas for estimating the shear strength of reinforced concrete structures without transverse reinforcement. The security factor of any reinforced concrete structure, against a possible collapse, is that it does not depend on the tensile strength of the concrete and the formation of any collapse is ductile, thus giving advance warning. The cracking from tensile stress can cause breakage of the concrete and should be avoided at all cost, with the intent that any such breakage does not incur any type of failure within the structure. In the present research study, experiments were performed in order to analyze the complementary mechanisms of the shear strength of lattice beams of reinforced concrete frames without transverse reinforcement. The experimental program entails the testing of eight frames that were subjected to a simple bending process. Two concrete resistance classes for analyzing compressive strength were considered on the construction of frames, $20 \mathrm{MPa}$ and $40 \mathrm{MPa}$. To resist the bending stresses, the beams of the frames are designed in domain 3 of the ultimate limit states. Different rates and diameters of longitudinal reinforcement were used, $1.32 \%$ and $1.55 \%$ with $12.5 \mathrm{~mm}$ diameter and $16.0 \mathrm{~mm}$ in longitudinal tensile reinforcement. From the obtained results, an analysis was made of the criteria already proposed for defining the norms pertinent to the portion of relevant contribution for the shear resistance mechanisms of concrete without the use of transverse reinforcement and the influence of the concrete resistance and longitudinal reinforcement rates established in the experimental numerical results.
\end{abstract}

Keywords: reinforced concrete, shear, cracking, additional mechanisms.

\section{Resumo}

Há muitas teorias e fórmulas empíricas que estimam a resistência ao cisalhamento de estruturas de concreto armado sem armadura transversal. A segurança de qualquer estrutura de concreto armado, em relação a um possível colapso, é que ela não dependa da resistência a tração do concreto, assim, o colapso é de forma dúctil, com aviso prévio. A fissuração, proveniente de esforços de tração, pode causar a ruptura do concreto e deve ser evitada para que não ocorra nenhum tipo de falha na estrutura. Nesta pesquisa foram realizados experimentos para analisar os mecanismos complementares ao de treliça de resistência ao cisalhamento em vigas de pórticos de concreto armado sem armadura transversal. O programa experimental consistiu no ensaio de oito pórticos e os modelos foram submetidos à flexão simples. Foram consideradas duas classes de resistências à compressão do concreto para a concretagem dos modelos, $20 \mathrm{MPa}$ e $40 \mathrm{MPa}$. Para resistir os esforcos de flexão, as vigas foram dimensionadas no domínio 3 do estado limite último. Foram usadas duas taxas de armadura, 1,32\% e 1,55\% com diâmetros de 12,5 mm e 16,0 $\mathrm{mm}$ de armaduras longitudinais de tração. A partir dos resultados obtidos foram analisados os critérios já propostos por normas para definir a parcela da contribuição relativa aos mecanismos resistentes de cisalhamento do concreto sem o uso de armadura transversal e a influência das resistências do concreto e taxas de armadura longitudinal nos resultados numéricos obtidos experimentalmente.

Palavras-chave: concreto armado, cisalhamento, fissuração, mecanismos complementares. 


\section{Introduction}

Ruptures in reinforced concrete beams are subject to the characteristics of the constituent material, concrete and steel, the dimensions of the element, the type of load and the design and details of the reinforcing steel, where a desired requirement is that it be of a ductile type. The study made by Fusco [1] conveys that while the main traction stress, which exists at the heart of the piece, does not cause a rupture in the concrete through traction, then the concrete resists the effects of shear.

In order to calculate the shear strength of a beam, many codes, norms and models simply recommend the overlapping of shear strength due to the concrete possessing a greater resistance capacity through its shear reinforcement.

The ABNT NBR 6118:2014 [2] states that the resistance of a beam to shear, shear strength, is usually considered from two portions, $\mathrm{V}_{\mathrm{c}}$ is the portion that is resisted by the concrete and complementary mechanisms on the truss, that contribute to the concrete and $\mathrm{V}_{\mathrm{sw}}$ the portion resisted by the transverse reinforcement.

The design calculation in [3] is presented through the truss analogy of Ritter and Morsch at the beginning of the XX century, where they associate a reinforced concrete beam to an equivalent trussed structure. Therefore, for beams with stirrups models based on strut and tie or on stress fields can be applied for the design [4].

The truss analogy is on the one hand easy to understand and highly didactic, but on the other is a very simple representation of the real structural behaviour, Figure 1. It therefore becomes clear that more refined models are necessary to improve and produce a more economical structural project for reinforced concrete beams, Wilder et al. [5].

In regards to shear strength in beams without transverse reinforcement, there does not exist a consensus in the available codes and norms concerning the parameters and phenomena that govern the problem of shear, which in many cases are based on empirical formulas $[6,7,8]$.

In the case of rectangular beams, with the format of an inclined crack, the shear stress transferred through the various mechanisms is proportionally $20 \%$ to $40 \%$ for the non-cracked concrete compression zone, $33 \%$ to $50 \%$ for the aggregate mesh and $15 \%$ for the pin effect, KIM and PARK [10]. In Yang [11], the importance of the interlocking of aggregates is brought to the fore concerning shear stress, which aids in the transference of forces after cracking starts.

The type of opening and relative dislocation of the crack develops normal tangential stresses, which are limited by the roughness of the contact surface. Emphasis is given here to the point that the roughness of the cracked surface is influenced by the size of the aggregate as well as by the real format of the crack, Ruiz et al. [8]. Besides the meshing of aggregates, other shear stress transference mechanisms were cited in Ruiz et al. [8], such as the resistance to concrete traction, the arc effect and the pin effect. In Bentz [12], shear strength is explained through a consideration of aggregate meshing in accordance with Walraven [9].

\section{Method for calculating the shear strength of concrete (Vc)}

\subsection{ABNT NBR 6118:2014}

In the case of elements with cross section reinforcement,

$V_{s d} \leq V_{r d 3}=V_{c}+V_{s w}$

$V_{c}=V_{c 0}$ For simple bending and flexion traction with the neutral line cutting the section,

$V_{c}=V_{c o}=0,6 \cdot f_{c t d} \cdot b_{w} \cdot d$

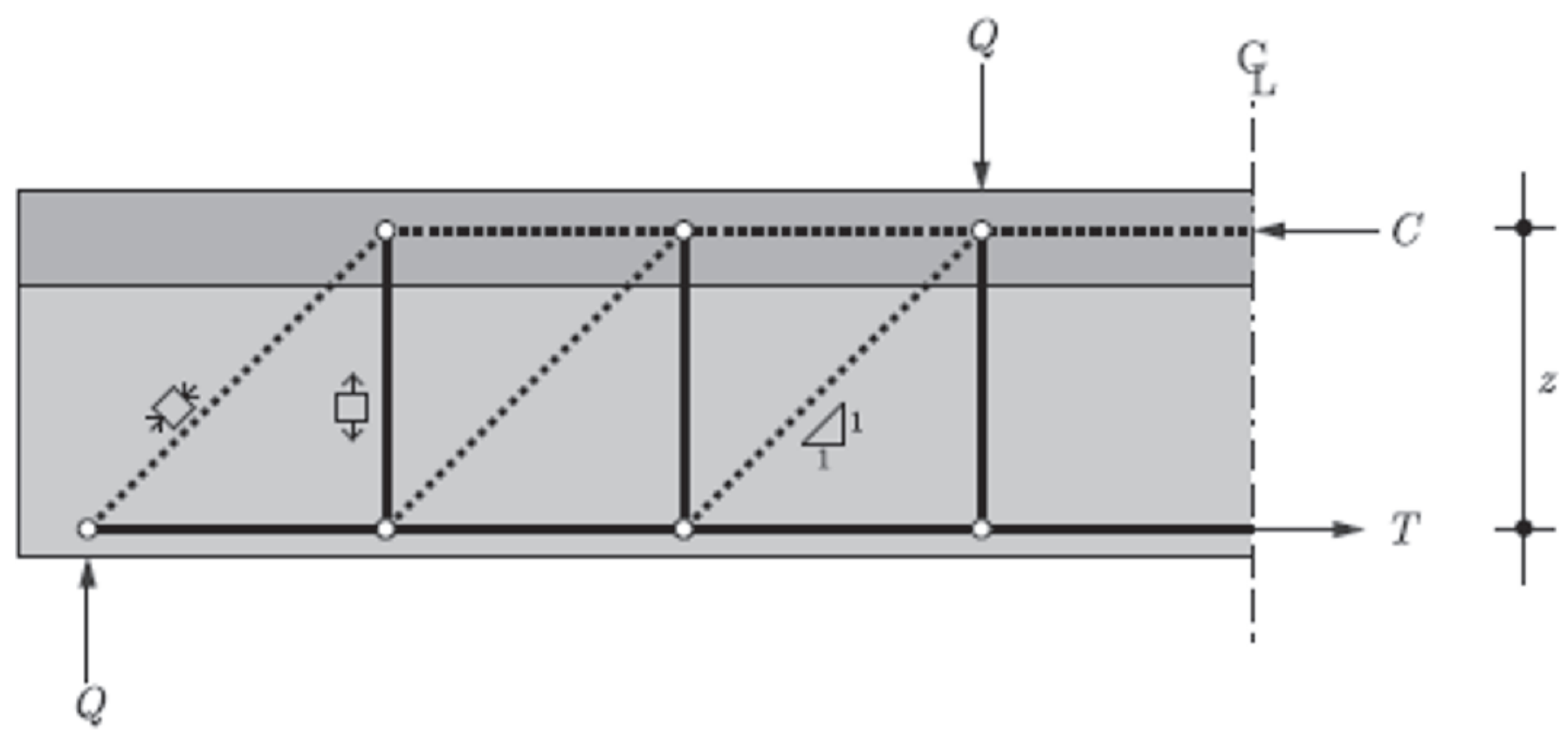

Figure 1

Truss analogy proposed by Ritter and Morsch (5) 
$\mathrm{V}_{\mathrm{sw}}=\left(\frac{\mathrm{A}_{\mathrm{sw}}}{\mathrm{s}}\right) \cdot 0,9 \cdot \mathrm{d} \cdot \mathrm{f}_{\mathrm{ywd}}$

(3)

Where:

$V_{\text {d }}$ - Shear stress requesting calculation, in section,

$V_{r d 3}^{s d}$ - Shear stress resisting calculation, related to the rupture by diagonal traction,

$V_{c}$ - Portion of absorbed shear through complementary mechanisms of the truss,

$V_{c 0}$ - Reference value for $V_{c}$, when $\theta=45^{\circ}$,

$f_{c t d}$ - Calculation for resistance of concrete to traction,

$b_{w}-$ Width of cross section,

$d$ - Useful height,

$A_{s w}$ - Reinforced cross section,

$S$ - Spacing between elements of reinforced cross section $A_{c y}$ measured in accordance with the longitudinal axis of the structural element.

$f_{c t d}=\frac{f_{c t k, \text { inf }}}{\gamma_{c}}$

The resistance to indirect traction $\mathrm{f}_{\mathrm{ctsup}}$ should be obtained through laboratory tests performed according to ABNT NBR 7222 [13].

The resistance to direct traction $\mathrm{f}_{\mathrm{ct}}$ can be considered as equal to $\mathrm{f}_{\mathrm{ct}}=0,9 \cdot \mathrm{f}_{\mathrm{ct}, \mathrm{sp}}$.

\subsection{ACl 318-14}

Equation 22.5.5.1 of the norm ACI 318-14 [14] in section 22.5.5 determines in a simplified manner, the portion $V_{c}$ that corresponds to shear strength of the concrete is given by,

$$
V_{c}=0,17 \cdot \lambda \cdot \sqrt{f_{c}^{\prime}} \cdot b_{w} \cdot d
$$

Where,

$f_{c}^{\prime}$ - Resistance to concrete compression in $M P a$,

$b_{w}$ - Largura da seção transversal em $(\mathrm{mm})$,

$d$ - Distance from extreme compression fiber to centroid of longitudinal tension reinforcement in $(\mathrm{mm})$,

$\lambda$ - Reduction factor of the mechanical properties of the concrete type, concrete with normal weight $\lambda=1$ (Table 19.2.4.2 of $\mathrm{ACl}$ 314-14)

$V_{c}$ - Nominal shear strength of concrete in $N$.

A more detailed calculation of $V_{c}$ is made in accordance with the expressions from table 22.5.5.1 of $\mathrm{ACl} 318-14$ using less than three values,

$V_{c}=\left(0,16 \cdot \lambda \sqrt{f_{c}^{\prime}}+17 \cdot \rho_{w} \cdot \frac{V_{u} \cdot d}{M_{u}}\right) \cdot b_{w} \cdot d$

$V_{c}=\left(0,16 \cdot \lambda \sqrt{f_{c}^{\prime}}+17 \cdot \rho_{w}\right) \cdot b_{w} \cdot d$

$V_{c}=0,29 \cdot \lambda \cdot \sqrt{f_{c}^{\prime}} \cdot b_{w} \cdot d$

Where,

$\rho_{w}$ - Longitudinal reinforcement ratio,

$V_{u}$ - Shear stress on the section,

$M_{u}$ - Bending moment in section.
For a majority of the models the second part of expressions (6) and (7) takes a value of $0,01 \cdot \lambda \sqrt{f_{c}^{\prime}}$ as allowed through Equation 5.

\subsection{BS 8110-97}

The design of concrete and reinforcements in accordance with BS8110-97 [15] can be taken as elements of the strut and tie system. The rupture in beams through shear with transversal reinforcement consider the angle of compression struts as $\theta=30^{\circ}$. The shear stress $v$, in any cross section is given by equation,

$v=\frac{V}{b_{v} \cdot d}$

Where,

$b_{v}=$ width of the section in $(\mathrm{mm})$,

$d=$ effective height in $(\mathrm{mm})$.

Under no circumstances should $\mathrm{v}$ be greater than,

$0,85 \sqrt{f_{c u}} \leq v \leq 5 \mathrm{~N} / \mathrm{mm}^{2}=5 \mathrm{MPa}$

$\mathrm{f}_{\mathrm{cu}}=$ Resistance characteristic of concrete compression.

\subsection{EN 1992-1-1: 2004 EUROCODE 2}

The calculation model adopted by EUROCODE 2 [17] is based on the truss model with a recommended angle on the struts of compression $\theta$ at interval $45^{\circ} \leq \theta \leq 68.20^{\circ}$.

In section 6.2.2, equation 6.4 of the Eurocode allows for the calculation of shear stress on concrete beams without transversal reinforcement in non-cracked regions through bending is given by:

$V_{c}=V_{R d, c}=\frac{I \cdot b_{w}}{S} \cdot \sqrt{\left(f_{c t d}\right)^{2}+\alpha_{l} \cdot \sigma_{c p} \cdot f_{c t d}}$

Where,

$V_{c}$ em $N$

$f_{c t d}=$ Resistance characteristic of tensile concrete $M P a$,

$\alpha_{l} \leq 1,0$ For pre stressed bars, and $\alpha_{l}=1,0$ for other types of pre stresses,

$\sigma_{\mathrm{cp}}=$ Compressive stress in the concrete due to axial load, $\sigma_{c p}=\frac{N_{e d}}{A_{c}}$ Em MPa; $\mathrm{N}_{\mathrm{ed}}>0$ on compression,

$A_{c}$ - Cross section area of concrete,

$b_{w}, d$ - Width of the cross section in and effective depth in $(\mathrm{mm})$,

$I$ - Moment of inertia of the cross section,

$S$ - Static moment of the area above the axis of the centre of gravity for the section.

\subsection{CSA A23 3-04}

The design of the reinforced concrete parts is based on the field theory of modified compression with the angle of the compression struts at $\theta=35^{\circ}$. The Canadian norm CSAA23. 3-04 [16] in section 11.3.4 determines the value of the concrete to shear stress in accordance with equation,

$V_{c}=\phi_{c} \cdot \lambda \cdot \beta \cdot \sqrt{f_{c}^{\prime}} \cdot b_{w} \cdot d_{v}$

Onde:

$\phi_{c}=$ ' 0,65 Factor of concrete resistance, 

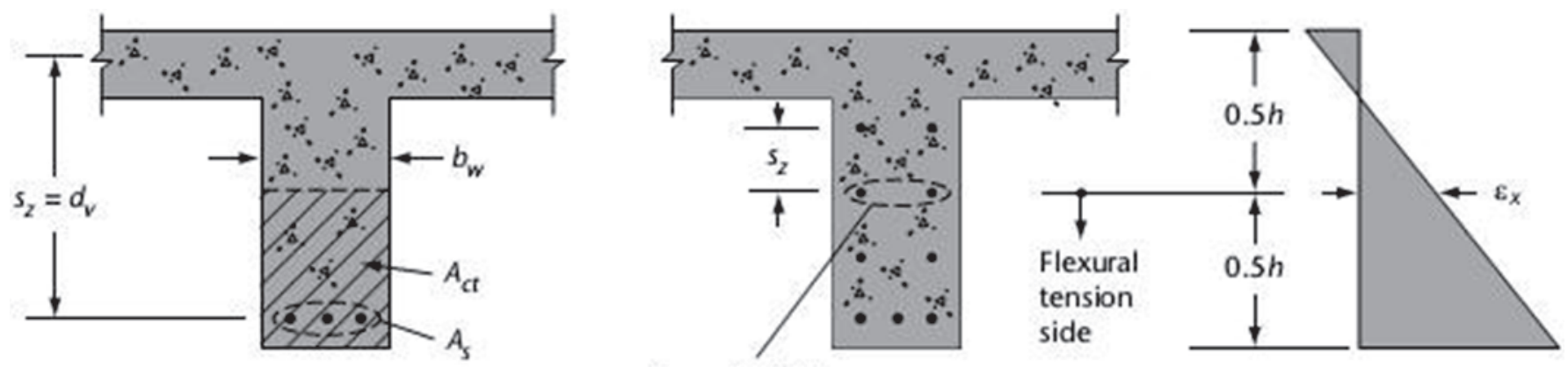

Area $\geq 0.003 b_{w} s_{z}$

\section{Figure 2}

Details of the transversal section for the calculation of $S_{z^{\prime}}$ adapted from (15)

$\beta=$ The factor responsible for the resistance of the cracked concrete, $\beta=0,21$

$\lambda=1,0=$ Density of normal concrete,

$b_{w}=$ Width of beam in $(\mathrm{mm})$,

$d_{v}=$ Effective shear depth in $(\mathrm{mm})$.

Resistance to compression of concrete should be less than or equal to $64 \mathrm{MPa}$ or

$\sqrt{f_{c}^{\prime}} \leq 8 M P a, 0,9 d \leq d_{v} \leq 0,72 h$ and $b_{w} \leq 250 m$

$f_{c}^{\prime}$ in $M P a, b_{w}, d_{v}$ in (mm), $V_{c}$ into $N$

The calculation of $\beta$ for the cross section without shear transversal resistance by the simplified method is given by,

a) If the section does not contain transversal reinforcement and the maximum nominal aggregate is not less than $20 \mathrm{~mm} \beta$ should be taken as,

$\beta=\frac{230}{\left(1000+d_{v}\right)}$

b) If the section does not contain transversal reinforcement, the value of $\beta$ can be determined by aggregate size, thus substituting the parameter $d_{v}$ in the equation of parameter $S_{z e}$, which allows the size of the aggregate and the equivalent value to be considered as $S_{z}$ and depends on the characteristics of the longitudinal reinforcement, where,

$S_{z e}=\frac{35 \cdot S_{z}}{15+a_{g}}$

(13)
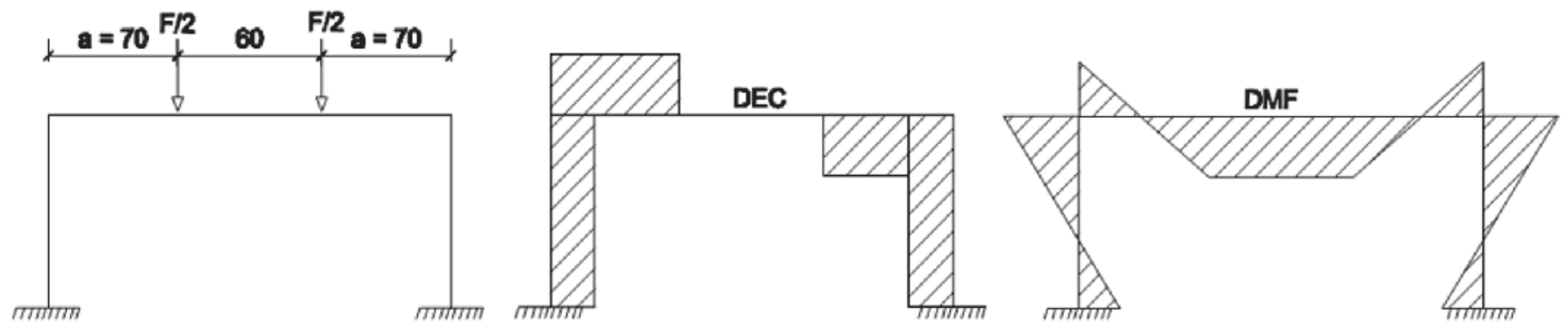

$a_{g}=$ Specified nominal maximum size of coarse aggregate,

$S_{z e} \geq 0,85 S_{z}$

$S_{z}$ - One should take $d_{v}$ or the maximum distance between the distribution lines of the longitudinal reinforcement, that which is the shortest. Each layer of longitudinal reinforcement should have an area of at least $0,003 \cdot b_{w} \cdot S_{z}$ as illustrated in Figure 2.

\subsection{FIB MODEL CODE 2010}

Resistance to shear for concrete parts without reinforcement, in accordance with the FIB Model Code 2010 [18] can be calculated through equation,

$V_{R d, c}=k_{v} \cdot \frac{\sqrt{f_{c k}}}{\gamma_{c}} \cdot b_{w} \cdot z$

Where,

$z=$ Internal lever arm or useful height in $(\mathrm{mm})$,

$b_{w}=$ Beam thickness in $(\mathrm{mm})$,

$\gamma_{c}=$ Concrete safety coefficient, $\gamma_{c}=1,50$,

$V_{R d, c}$ into $N$

$F_{c k}^{R d, c}$ into $\mathrm{MPa}$ and $\sqrt{f_{c k}} \leq 8 \mathrm{MPa}$ where,

$k_{v}=\frac{180}{1000+1,25 \cdot z}$

Figure 3

Diagram for load and forces 
Table 1

Identification of the models

\begin{tabular}{|c|c|c|c|c|c|c|c|}
\hline Series & Type & Model & $f_{c}(M P a)$ & $\begin{array}{l}\text { Longitudinal } \\
\text { reinforcement } \\
\text { traction }\end{array}$ & $A_{s l}\left(\mathrm{~cm}^{2}\right)$ & $\rho_{1}(\%)$ & $a / d$ \\
\hline \multirow{2}{*}{$\mathrm{Pl}$} & \multirow{2}{*}{ A } & $a$ & \multirow{4}{*}{20} & \multirow{2}{*}{$4 \varnothing 12,5 \mathrm{~mm}$} & \multirow{2}{*}{4,90} & \multirow{2}{*}{1,32} & \multirow{2}{*}{2,83} \\
\hline & & $b$ & & & & & \\
\hline \multirow{2}{*}{ P2 } & \multirow{2}{*}{ B } & $a$ & & \multirow{2}{*}{$3 \varnothing 16,0 \mathrm{~mm}$} & \multirow{2}{*}{6,03} & \multirow{2}{*}{1,55} & \multirow{2}{*}{2,67} \\
\hline & & $b$ & & & & & \\
\hline \multirow{2}{*}{ P3 } & \multirow{2}{*}{ A } & a & \multirow{4}{*}{40} & \multirow{2}{*}{$4 \varnothing 12,5 \mathrm{~mm}$} & \multirow{2}{*}{4,90} & \multirow{2}{*}{1,32} & \multirow{2}{*}{2,83} \\
\hline & & $b$ & & & & & \\
\hline \multirow{2}{*}{ P4 } & \multirow{2}{*}{ B } & a & & \multirow{2}{*}{$3 \varnothing 16,0 \mathrm{~mm}$} & \multirow{2}{*}{6,03} & \multirow{2}{*}{1,55} & \multirow{2}{*}{2,67} \\
\hline & & $b$ & & & & & \\
\hline
\end{tabular}

\section{Experimental program and materials}

\subsection{Frame features and properties of materials}

Four series of reinforced concrete frames were tested with a height of $1.10 \mathrm{~m}$ and $2.25 \mathrm{~m}$ in length with equidistant loads on the supports and crescents, Samora [19]. For each series, two frames were used with the same geometric features and variables, as such eight frames were tested.

The scheme for the loading of the frames and the diagrams of the stress corresponding to the free body are presented in Figure 3.

The experimental planning was mounted with the resistance factors, characteristic of concrete compression and the longitudinal reinforcement ratio of the beam, Table 1. The interest in variation or factor input levels is the shear resistance of the concrete on the rupture. The test models had a geometric ratio of longitudinal reinforcement of $1.32 \%$ for the type A frames and of $1.55 \%$ for type B frames.

The frame beams have a rectangular cross section of $15 \mathrm{~m}$ width, $30 \mathrm{~cm}$ in height by $2.25 \mathrm{~m}$ in length. The frame columns have a rectangular cross section of $15 \mathrm{~cm}$ in width and $25 \mathrm{~cm}$ in length and a height of $1.10 \mathrm{~m}$ from the support to the upper side of the beam. The dimensions and details of the frames are indicated in Figures 4 and 5 .
The concrete used in the test study was of ready-mix type, supplied by specialized companies. For the pairs P1, P2 and P3, P4 concrete of classes $\mathrm{C} 20$ and C40 was used respectively, and refer to an age of 28 days.

The results from the laboratory tests for resistance to concrete compression at diverse ages along with the values for the modules of elasticity and traction are presented on Tables 2 and 3.

On Table 4, dates are presented for the performing of the tests and the age of each part in relation to the date of concreting.

The ABNT 6118:2014 permits the verification of the resistance calculation for the concrete in $t$ (days) in relation to the age 28 days is given by the expression,

$f_{c d}=\frac{f_{c k, j}}{\gamma_{c}} \cong \beta_{1} \cdot \frac{f_{c k}}{\gamma_{c}}$

In this case, the weighting coefficient adopted for the concrete resistance is $\gamma_{c}=1$. The value for $\beta_{1}$ can be obtained by the expression,

$$
\beta_{1}=\exp \left\{s \cdot\left[1-\left(\frac{28}{t}\right)^{\frac{1}{2}}\right]\right\}
$$

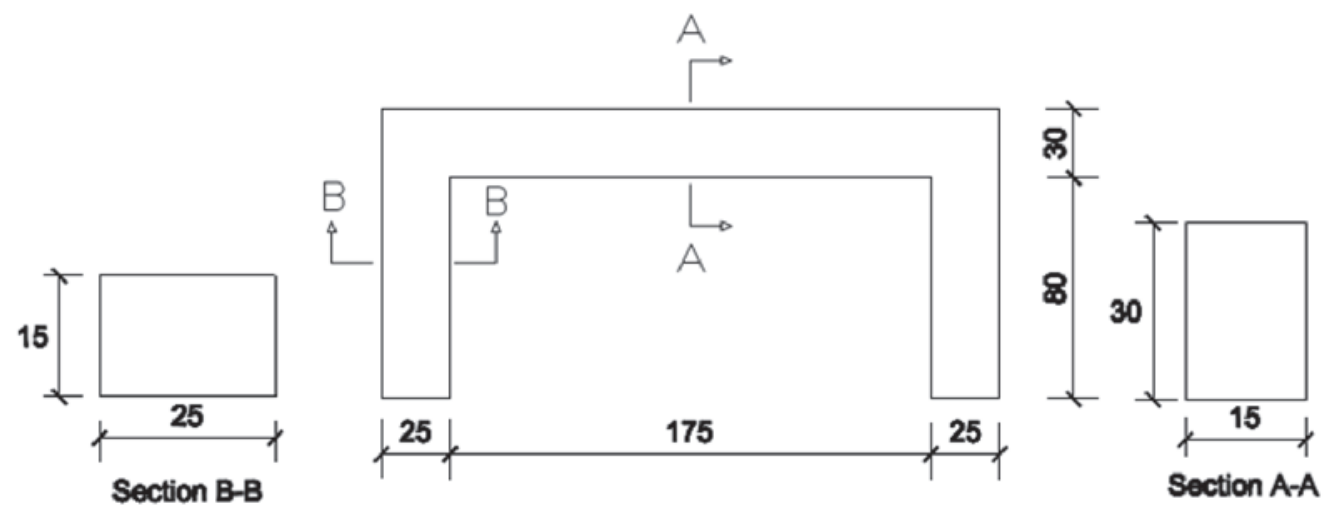

Figure 4

Frame dimensions - dimensions in $\mathrm{cm}$ 

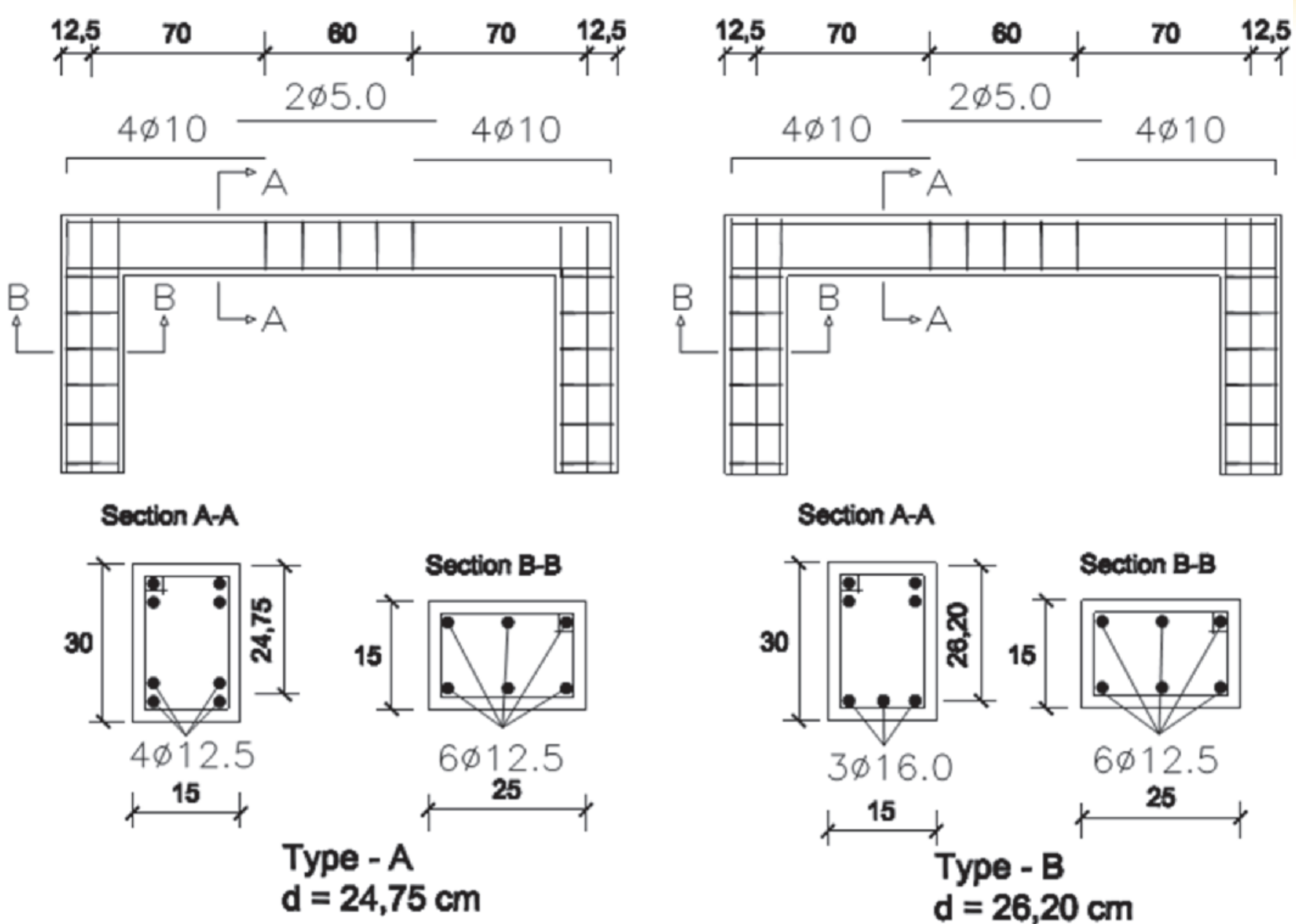

\section{Section A-A}

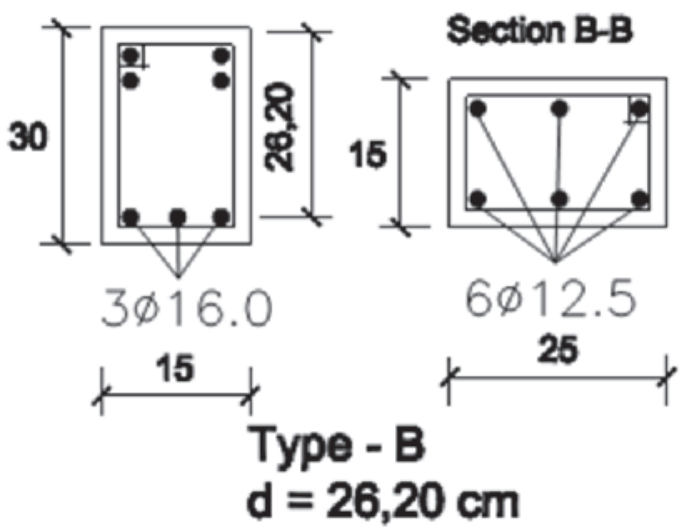

Figure 5

Details for frames, types A and B - dimensions in $\mathrm{cm}$

Table 2

Results from tests on compression strength of concrete from the frames

\begin{tabular}{|c|c|c|c|c|}
\hline Age (C) & $f_{c}(20 \mathrm{MPA})$ & $f_{c m}$ (MPA) & $\mathrm{f}_{\mathrm{c}}(40 \mathrm{MPA})$ & $f_{c m}(M P A)$ \\
\hline \multirow{2}{*}{$\mathrm{f}_{\mathrm{c}, 7 \text { days }}$} & 8,90 & \multirow{2}{*}{8,92} & 23,24 & \multirow{2}{*}{22,61} \\
\hline & 8,94 & & 21,29 & \\
\hline \multirow{2}{*}{$f_{c, 14 \text { days }}$} & 12,7 & \multirow{2}{*}{12,26} & 27,72 & \multirow{2}{*}{28,95} \\
\hline & 11,82 & & 30,18 & \\
\hline \multirow{2}{*}{$f_{c, 28 \text { days }}$} & 17,65 & \multirow{2}{*}{17,13} & 35,87 & \multirow{2}{*}{36,72} \\
\hline & 16,62 & & 37,57 & \\
\hline \multirow{2}{*}{$f_{c, 56 \text { days }}$} & 21,36 & \multirow{2}{*}{21,61} & 41,05 & \multirow{2}{*}{40,50} \\
\hline & 21,86 & & 39,95 & \\
\hline
\end{tabular}

Table 3

Results from tests on modulus of elasticity and tensile strength

\begin{tabular}{|c|c|c|c|c|c|}
\hline Concrete & Age (C) & $f_{c m}(M P A)$ & $\mathrm{E}_{\mathrm{c}}(\mathrm{GPA})$ & $\mathrm{f}_{\mathrm{ct}, \text { sup }}(\mathrm{MPA})$ & $\begin{aligned} f_{c t}=0,9 \cdot f_{c t, \text { sup }} & (M P A)\end{aligned}$ \\
\hline$f_{c}(20 M P a)$ & 56 days & 21,54 & 28,79 & 2,45 & 2,21 \\
\hline$f_{c}(40 M P a)$ & 56 days & 44,13 & 36,30 & 3,98 & 3,58 \\
\hline
\end{tabular}


Table 4

Age of specimen

\begin{tabular}{|c|c|c|c|c|c|c|}
\hline Series & Type & Model & $f_{c}(M P a)$ & Date of concreting & Date of test & Age (days) \\
\hline \multirow{2}{*}{$\mathrm{Pl}$} & \multirow{2}{*}{ A } & $a$ & \multirow{4}{*}{20} & \multirow{8}{*}{$04 / 04 / 2014$} & $07 / 08 / 2014$ & 125 \\
\hline & & $\mathrm{b}$ & & & $11 / 07 / 2014$ & 98 \\
\hline \multirow{2}{*}{ P2 } & \multirow{2}{*}{ B } & $a$ & & & $18 / 07 / 2014$ & 105 \\
\hline & & $b$ & & & $04 / 07 / 2014$ & 91 \\
\hline \multirow{2}{*}{ P3 } & \multirow{2}{*}{ A } & a & \multirow{4}{*}{40} & & $16 / 06 / 2014$ & 73 \\
\hline & & $\mathrm{b}$ & & & $24 / 07 / 2014$ & 111 \\
\hline \multirow{2}{*}{ P4 } & \multirow{2}{*}{ B } & $a$ & & & $27 / 06 / 2014$ & 84 \\
\hline & & $b$ & & & $01 / 08 / 2014$ & 119 \\
\hline
\end{tabular}

Table 5

Probable compression strength estimated for the concrete

\begin{tabular}{|c|c|c|c|c|c|c|}
\hline Series & Type & Model & $f_{c, 28 \text { days }}(M P a)$ & $f_{c, 56 \text { days }}(M P a)$ & Age (days) & $\begin{array}{l}\text { Estimated probable } \\
\text { strength (MPa) }\end{array}$ \\
\hline \multirow{2}{*}{$\mathrm{Pl}$} & \multirow{2}{*}{ A } & $a$ & \multirow{4}{*}{17,13} & \multirow{4}{*}{21,60} & 125 & 19,54 \\
\hline & & $b$ & & & 98 & 19,24 \\
\hline \multirow{2}{*}{ P2 } & \multirow{2}{*}{ B } & $a$ & & & 105 & 19,33 \\
\hline & & $b$ & & & 91 & 19,15 \\
\hline \multirow{2}{*}{ P3 } & \multirow{2}{*}{ A } & $a$ & \multirow{4}{*}{36,72} & \multirow{4}{*}{40,50} & 73 & 40,39 \\
\hline & & $\mathrm{b}$ & & & 111 & 41,59 \\
\hline \multirow{2}{*}{ P4 } & \multirow{2}{*}{ B } & a & & & 84 & 40,81 \\
\hline & & $b$ & & & 119 & 41,76 \\
\hline
\end{tabular}

With,

$s=0,38$ for concrete from cement CPIII and CPIV

$s=0,25$ for concrete from cement CPI and CPII

$s=0,20$ for concrete from cement CPV-ARI

$t=$ effective age of the concrete, in days.

Table 5 presents the probable resistance to compression estimated for the concrete used in the frames on the date of the laboratory tests.

One affirms that there was no influence in relation to the age of the concrete used in the frames on the data of the test to the variation that occurred on the compression resistance, in relation to the value obtained through the testing of cylindrical specimens of 10 $\mathrm{cm} \times 20 \mathrm{~cm}$ at 56 days of age for the frame concrete, which was adopted for the calculations and considerations of the study.

Table 6 presents the measured results obtained for the mechanical properties from the steel bars.

\subsection{Instrumentation}

The specific deformations on the reinforcements and the concrete were measured by electric extensometers from Excel Sensores.

\section{Table 6}

Test results for traction on the steel bars

\begin{tabular}{|c|c|c|}
\hline$\varnothing(\mathbf{m m})$ & $\mathbf{f}_{\mathrm{y}}(\mathbf{M P a})$ & $\mathbf{E}_{\mathrm{s}}(\mathbf{M P a})$ \\
\hline 12,5 & 603,60 & $193.073,00$ \\
\hline 16,0 & 584,25 & $206.854,00$ \\
\hline
\end{tabular}

These meters were stuck to the longitudinal reinforcements and the concrete by means of cyanoacrylate based adhesive, isolated and sealed with plastic tape as shown in Figure 6. These extensometers stuck to the longitudinal reinforcements were designated by the letter $\mathrm{L}$, those immersed in the concrete letter I, and those stuck to the compressed side of the concrete, letter $\mathrm{C}$.

\subsection{Equipment used in the tests}

For applying the loads the metallic frame was used, which was mounted on a response slab at the structures laboratory at UFU. The load was applied by the hydraulic actuator feed by a manual pump and transferred to two symmetrical points away from the beam at $70 \mathrm{~cm}$ at each extremity, by means of a beam made up of a metallic profile "l" $250 \mathrm{~mm} \times 44.80 \mathrm{~kg} / \mathrm{m}$. For the measuring of the load, a load cell was employed, made up of a steel cylinder with the resistance electric extensometer calibrated until $500 \mathrm{kN}$ placed on it, as shown in Figure 7. The load was applied with increases of $15 \mathrm{kN}$. At each stage of loading, observations were made and registered on panoramic video of the cracks that occurred on the frame. The rate at which the load increased one noted the evolution of the cracks, which were marked with crayon on the concrete surface, Figure 8.

Through the use of electric extensometers linked to the data logger, measurements were made of the deformations of the reinforcements and the concrete.

\section{Results and discussions}

The values for the portion of shear stress resisted by complementary 


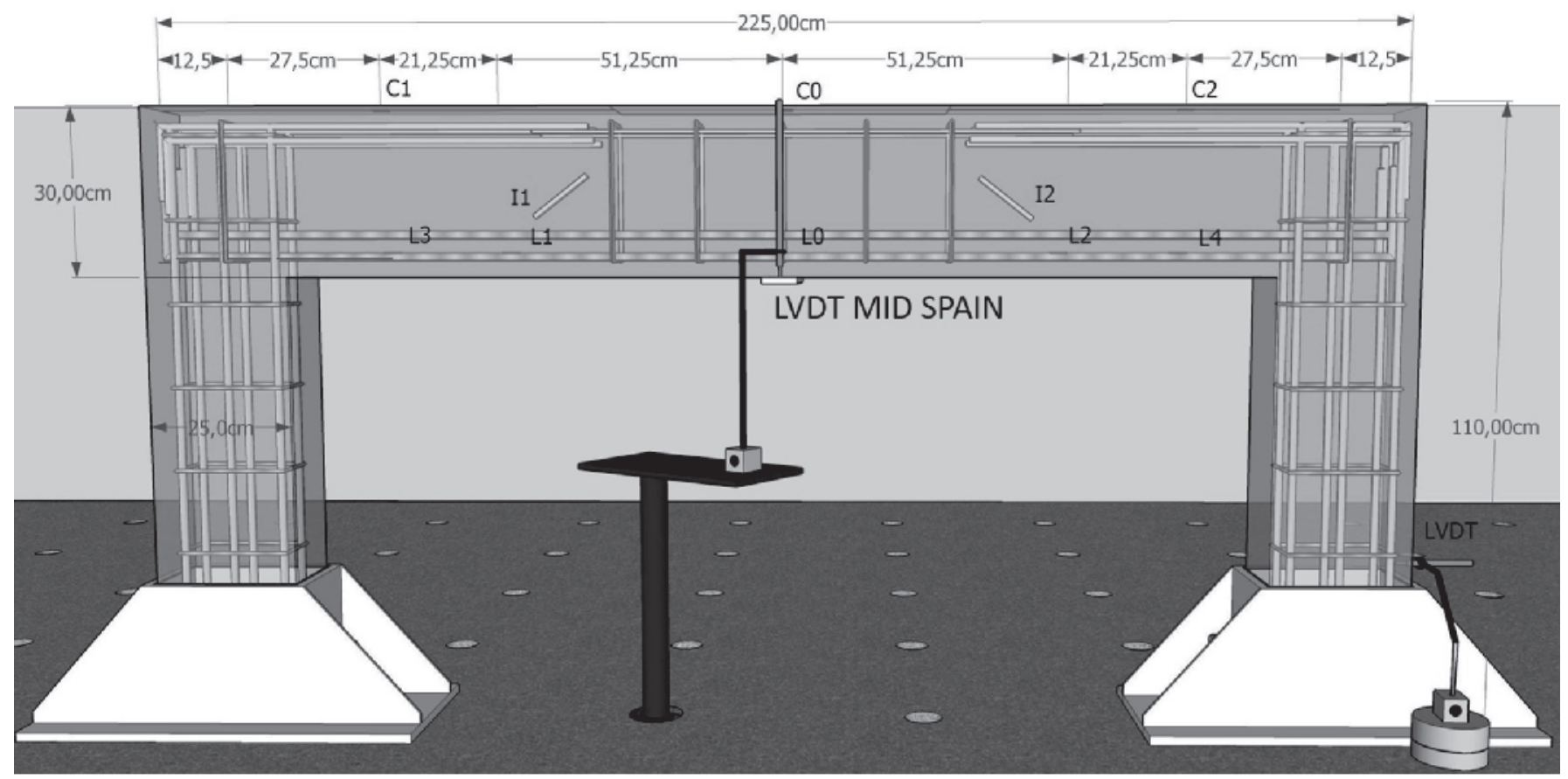

\section{Figure 6}

General position of extensometers on the frame

mechanisms were calculated as defined by the norms ABNT NBR 6118:2014 [2], ACI 318-14 [14], BS 8110-97 [15], EN 1992-1-1-2004 [17], CSAA23. 3-04 [16] and FIB MODEL CODE 2004 [18], Table 7.
Through the longitudinal reinforcement proposed, the theoretical value of the last moment of longitudinal reinforcement flow was calculated in accordance with the hypotheses of
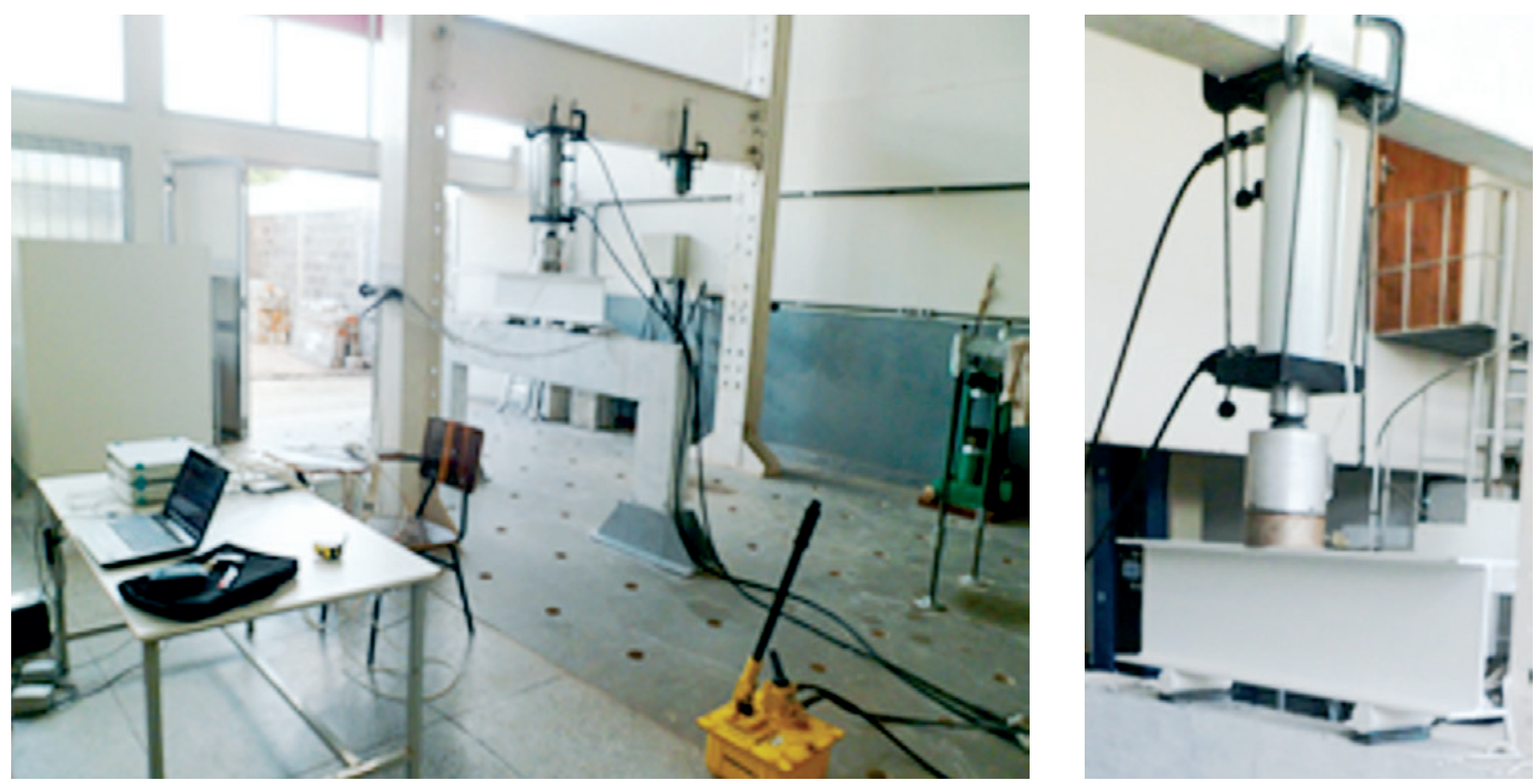

Figure 7

General view and details of the load application point 


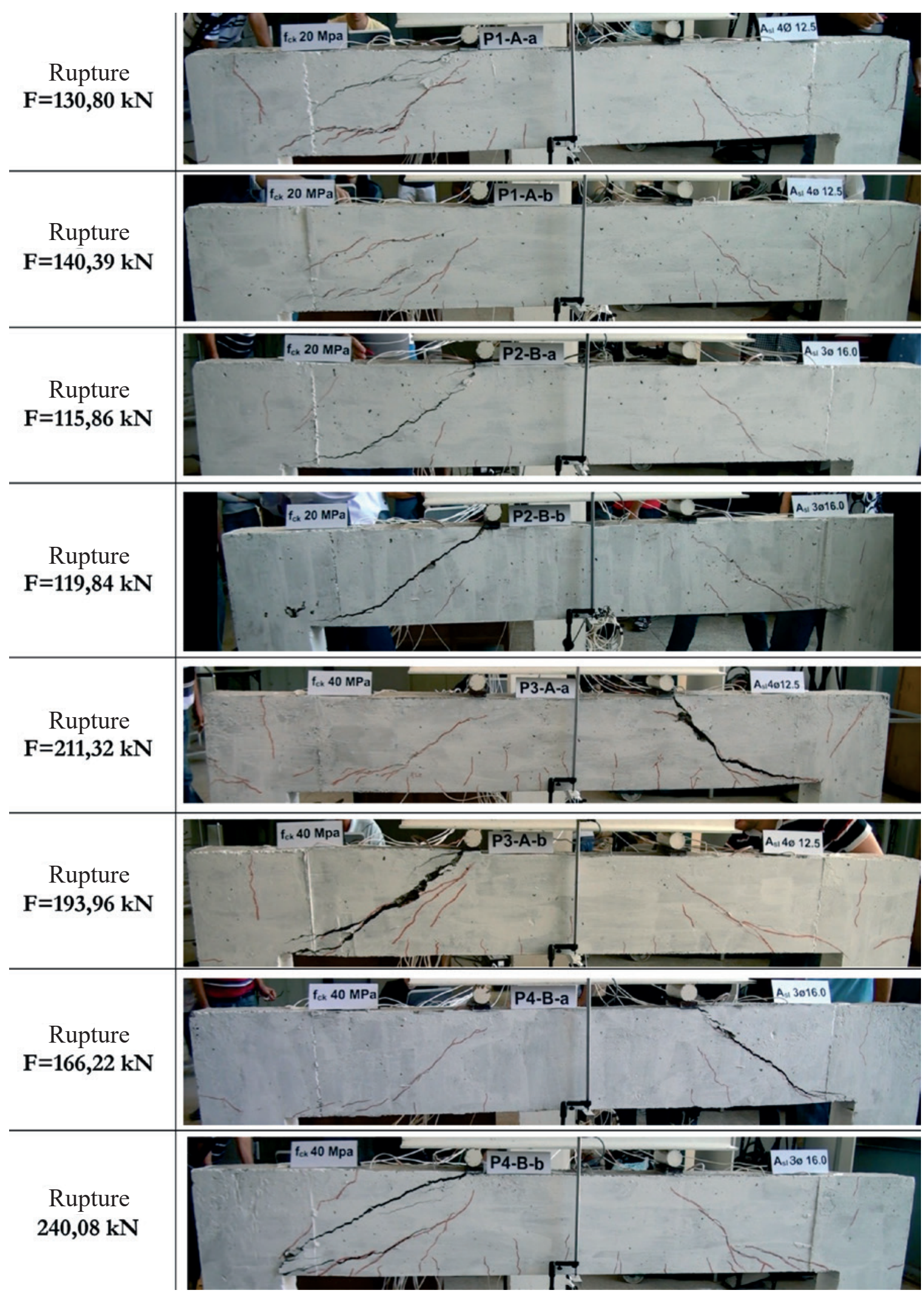

Figure 8

Panorama of cracks in the frames and rupture loads 
Table 7

Strength values in accordance with norms

\begin{tabular}{|c|c|c|c|c|c|c|}
\hline \multirow[b]{2}{*}{ Frames } & \multicolumn{6}{|c|}{$\mathrm{V}_{\mathrm{c}}(\mathrm{kN})$} \\
\hline & $\begin{array}{l}\text { ABNT NBR } \\
6118: 2014\end{array}$ & $\mathrm{ACl} 318-14^{(8)}$ & BS $8110-97$ & $\begin{array}{c}\text { EN 1992-1-1- } \\
2004\end{array}$ & $\begin{array}{c}\text { CSA A 23.3-04 } \\
a_{g}=20 \mathrm{~mm}\end{array}$ & FIB CODE 2004 \\
\hline Pl-A-a & \multirow{2}{*}{49,22} & \multirow{2}{*}{50,04} & \multirow{2}{*}{36,29} & \multirow{4}{*}{66,30} & \multirow{2}{*}{20,63} & \multirow{4}{*}{25,31} \\
\hline Pl-A-b & & & & & & \\
\hline P2-B-a & \multirow{2}{*}{52,11} & \multirow{2}{*}{52,97} & \multirow{2}{*}{39,95} & & \multirow{2}{*}{21,61} & \\
\hline P2-B-b & & & & & & \\
\hline P3-A-a & \multirow{2}{*}{79,74} & \multirow{2}{*}{68,52} & \multirow{2}{*}{42,64} & & \multirow{2}{*}{28,25} & \multirow{4}{*}{34,67} \\
\hline P3-A-b & & & & 10740 & & \\
\hline P4-B-a & \multirow{2}{*}{84,41} & \multirow{2}{*}{72,53} & \multirow{2}{*}{46,90} & 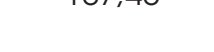 & \multirow{2}{*}{29,59} & \\
\hline P4-B-b & & & & & & \\
\hline
\end{tabular}

\section{Table 8}

Comparison of calculated and experimental values

\begin{tabular}{|c|c|c|c|c|c|}
\hline \multirow[b]{2}{*}{ Frames } & \multicolumn{2}{|c|}{ Calculated values } & \multicolumn{2}{|c|}{ Experimental values } & \multirow[b]{2}{*}{$\mathrm{V}_{\mathrm{u}, \exp } / \mathrm{V}_{\mathrm{u}, \mathrm{cal}}$} \\
\hline & $\mathrm{V}_{\mathrm{u}, \mathrm{cal}}(\mathrm{kN})$ & $\mathrm{M}_{\mathrm{u}, \mathrm{cal}}(\mathrm{kN} \cdot \mathrm{m})$ & $\frac{F}{2}=V_{u}(k N)$ & $M_{u, \exp }(k N \cdot m)$ & \\
\hline P1-A-a & \multirow{2}{*}{150,30} & \multirow{2}{*}{57,34} & 65,40 & 25,00 & 0,435 \\
\hline P1-A-b & & & 70,20 & 26,80 & 0,467 \\
\hline P2-B-a & \multirow{2}{*}{189,60} & \multirow{2}{*}{69,89} & 57,93 & 22,10 & 0,316 \\
\hline P2-B-b & & & 59,92 & 22,90 & 0,327 \\
\hline P3-A-a & \multirow{2}{*}{169,50} & \multirow{2}{*}{64,68} & 105,66 & 40,30 & 0,623 \\
\hline P3-A-b & & & 96,98 & 37,00 & 0,572 \\
\hline P4-B-a & \multirow{2}{*}{210,00} & \multirow{2}{*}{80,32} & 83,11 & 31,70 & 0,397 \\
\hline P4-B-b & & & - & - & - \\
\hline
\end{tabular}

Observation: The results for frame P4-B-b were withdrawn as they did not obtain randomly distributed values around an average value and did not follow the tendency of the samples.

ABNT NBR 6118:2014 [2], where rectangular distribution on the stresses of the concrete compression was admitted. This bending moment corresponds to a shear force, the last to be obtained through use of the program Ftool [20]. Table 8 presents the comparative results of the theoretical value with the experimental value. The comparison $\frac{V_{u, \text { exp }}}{V_{u, \text { calc }}}$, of the experimental results in relation to the last shear stress values obtained from the calculated values,

\section{Table 9}

Strength variation of the complementary mechanisms in function of the concrete compression strength

\begin{tabular}{|c|c|c|}
\hline Frames & $\frac{\mathbf{F}}{\mathbf{2}}=\mathbf{V}_{\mathbf{u}}(\mathbf{k N})$ & $\Delta(\%)$ \\
\hline $21,60 \mathrm{MPa}-1,32 \%$ & 67,80 & \multirow{2}{*}{49,44} \\
\cline { 1 - 2 } $40,50 \mathrm{MPa}-1,32 \%$ & 101,32 & \\
\cline { 1 - 2 } $21,60 \mathrm{MPa}-1,55 \%$ & 58,93 & \multirow{2}{*}{41,03} \\
\cline { 1 - 2 } $40,50 \mathrm{MPa}-1,55 \%$ & 83,11 & \\
\hline
\end{tabular}

shows that the frames with the highest ratio of reinforcement $\rho_{l}=1,5 \%$ (P2 e P4) present the lowest shear relation when compared to the shear relation of the frames with the lowest ratio of reinforcement $\rho_{l}=1,32 \%$ (P1 e P3).

Table 9 presents the results of the resistance variation of shear of the complementary mechanisms, which maintained constant percentages of longitudinal reinforcement in function of the concrete compression resistance.

One notes that for the frame beams analysed without transversal reinforcement, with the same ratio of longitudinal reinforcement, there was an increase in shear strength from the complementary mechanisms of the truss, with an increase in resistance to concrete compression. Figures 9 and 10, present the comparison of load resistance of the beams with the same resistance to concrete compression, by varying the ratio of reinforcement. Stated here is that beams that possess lower ratios of reinforcement to the same concrete compression resistance, support higher loads.

Upon the analysis of the beam deformations with a higher value given to the bending moment, extensometer $L 0$, Figure 11 , one notes that the reinforcements do not reach the maximum admitted flow by the norm of $10 \mathrm{~mm} / \mathrm{m}$. The highest value obtained was $0.0013 \mathrm{~mm} / \mathrm{m}$ for beam P1-A-a, confirming the rupture of the beams by shear stress and not simple bending. 


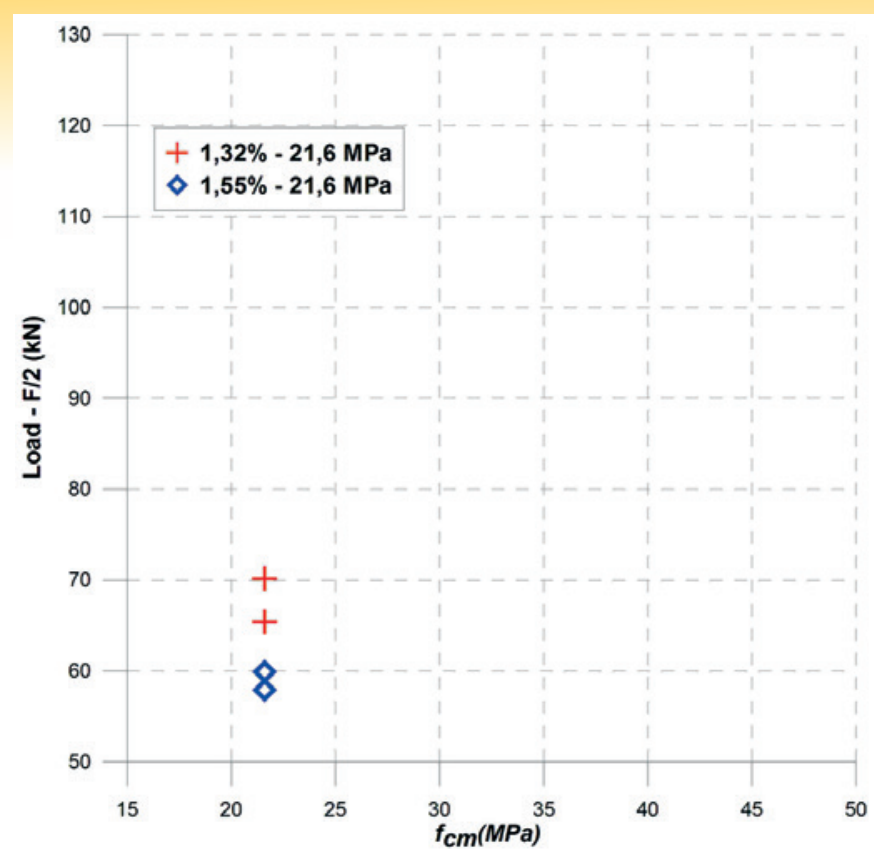

Figure 9

Variation of the longitudinal reinforcement ratio/ concrete compression strength $21.6 \mathrm{MPa}$

Table 8 shows the results for the comparison of the experimental values of the resistant portion of the concrete to shear without transversal reinforcement $\left(V_{u \text {,exp }}\right)$ in relation to the values of $\left(V_{c}\right)$ calculated by the norms $[2,14,15,16,17,18]$.

One notes that there is a great variation in the values calculated by the norms compared to the experimental values. The ABNT NBR 6118:2014 and the $\mathrm{ACl} 318-14$ are those that most converge the calculated values with a difference of approximately $10 \%$, Table 10 .

\section{Conclusions}

This work had as its objective to present the analyses of the

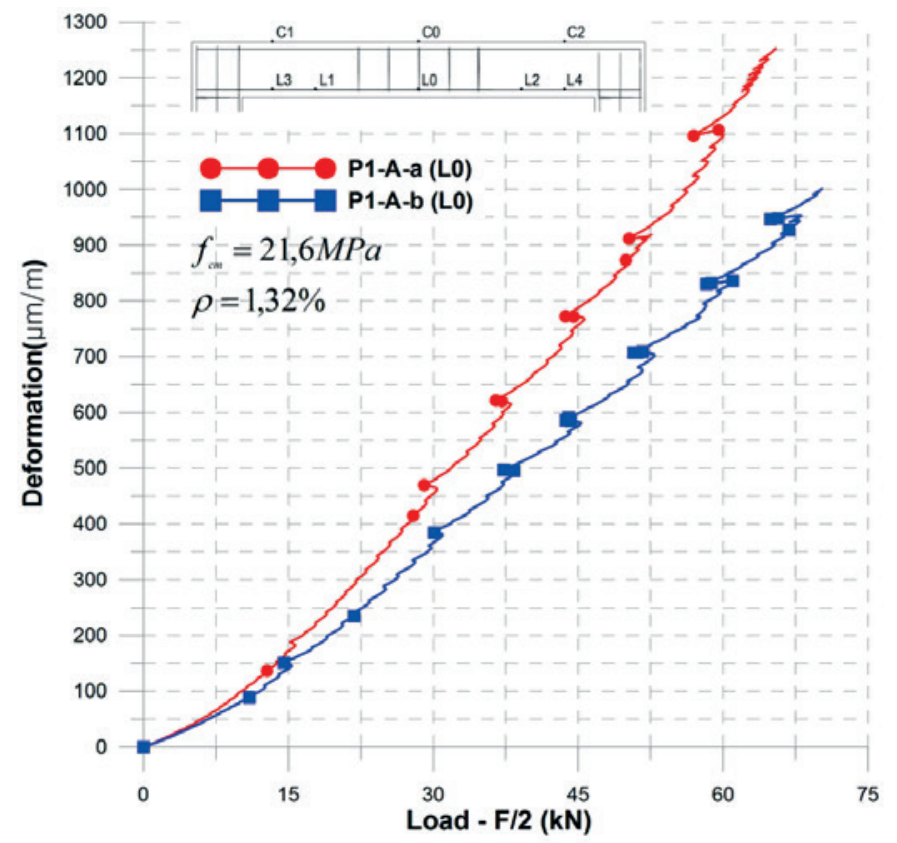

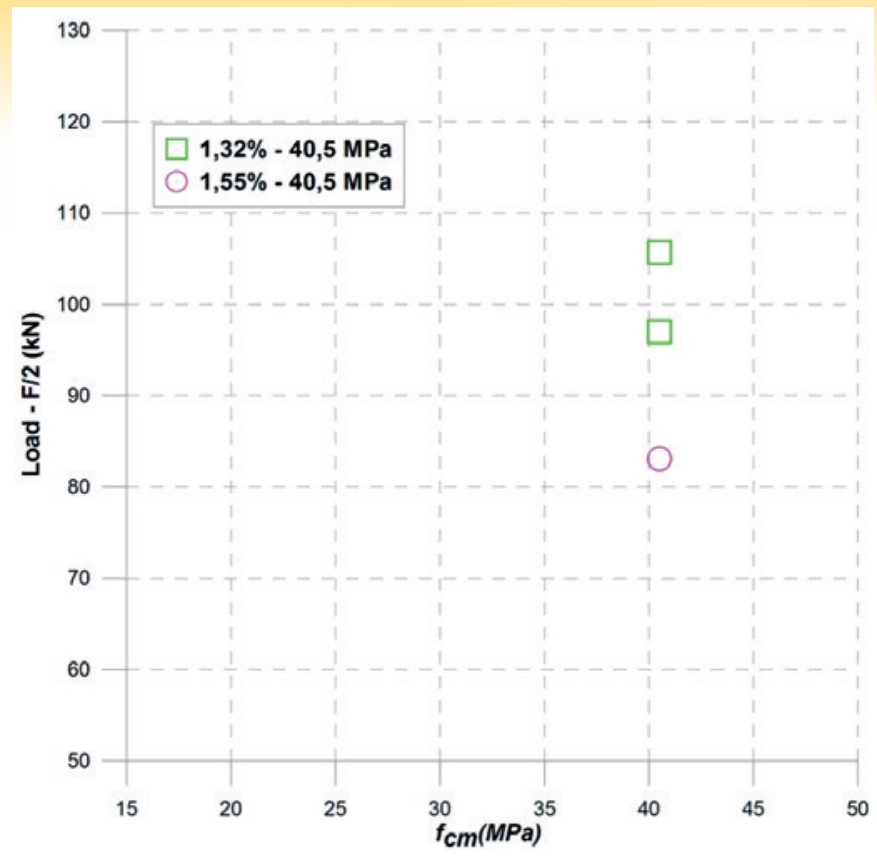

Figure 10

Variation of the longitudinal reinforcement ratio/ concrete compression strength $40.5 \mathrm{MPa}$

experimental results concerning the portion of shear stress strength $V_{c}$, in beams from embedded frames, with the strength variation characteristic of concrete and the ratio of longitudinal reinforcement. One concludes that,

1) With the lower ratio of longitudinal reinforcement, maintaining constant the strength characteristics of the concrete, there was an increase in strength of the complementary mechanisms of truss, when faced with shear. Based on the tensile and compression stresses applied to the concrete by a bar of steel of stress to be transferred by the pin effect, the maximum transferred stress through the pin effect was negatively affected with the increase in the diameter of the bars.

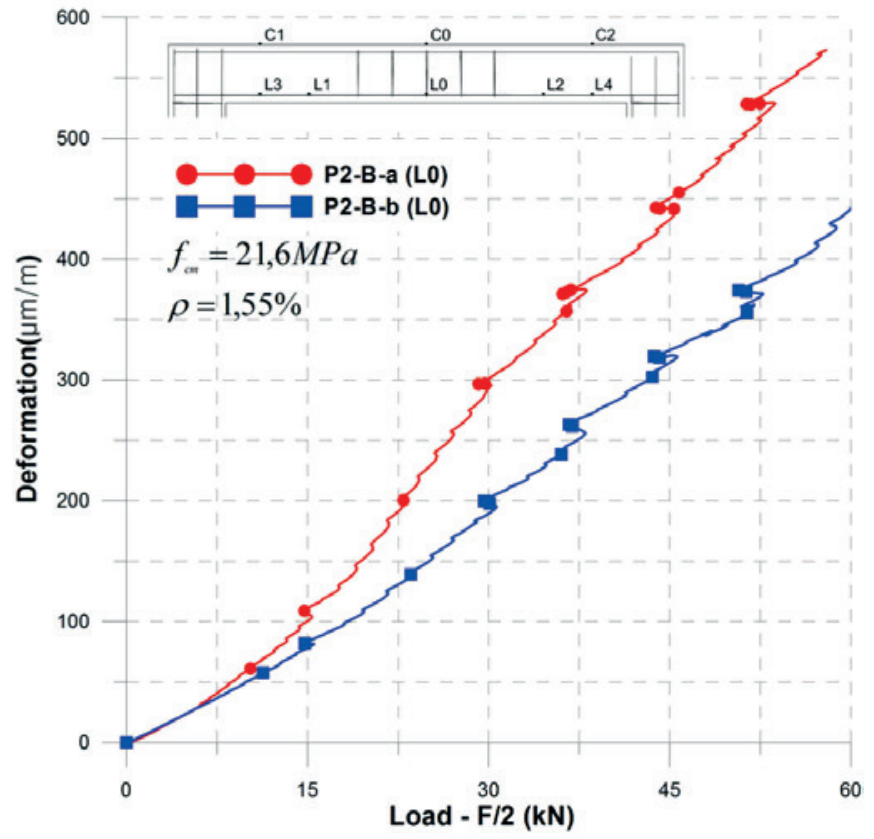

Figure 11

Deformation on the longitudinal reinforcement (LO) for the columns of series P1-A and P2-B 
Table 10

Comparison between experimental and calculated values of the norms

\begin{tabular}{|c|c|c|c|c|c|c|}
\hline \multirow{2}{*}{ Frames } & \multicolumn{9}{|c|}{$\mathrm{V}_{\mathrm{u}, \text { exp }} / \mathrm{V}_{\mathrm{c}}$} \\
\cline { 2 - 7 } & ABNT NBR 61 18:2014 & ACI 318-14 (8) & BS 81 10-97 & EN 1992-1-1:2004 & $\begin{array}{c}\text { CSA A23.3.04 } \\
\mathbf{a}_{\mathrm{g}}=\mathbf{2 0 m m}\end{array}$ & $\begin{array}{c}\text { FIB CODE } \\
\mathbf{2 0 1 4}\end{array}$ \\
\hline P1-A-a & 1,328 & 1,307 & 1,802 & 0,986 & 3,170 & 2,584 \\
\hline P1-A-b & 1,426 & 1,403 & 1,934 & 1,059 & 3,403 & 2,774 \\
\hline P2-B-a & 1,112 & 1,094 & 1,450 & 0,874 & 2,681 & 2,289 \\
\hline P2-B-b & 1,149 & 1,131 & 1,500 & 0,904 & 2,773 & 2,368 \\
\hline P3-A-a & 1,325 & 1,542 & 2,469 & 0,984 & 3,740 & 3,048 \\
\hline P3-A-b & 1,216 & 1,415 & 2,274 & 0,903 & 3,433 & 2,797 \\
\hline P4-B-a & 0,985 & 1,146 & 1,772 & 0,774 & 2,809 & 2,390 \\
\hline P4-B-b & - & - & - & - & - & - \\
\hline$V_{u, e x p} / V_{c}$ & 1,216 & 1,307 & 1,802 & 0,904 & 3,170 & 2,584 \\
\hline
\end{tabular}

2) With the increase in strength characteristic of concrete under compression, maintaining constant the ratio of longitudinal reinforcement of the beam, the experimental results show an increase in strength in the complementary mechanisms of the truss, when faced with shear, evincing therefore a higher mobilization by the meshing of the aggregates.

3) Regarding values obtained experimentally compared to calculation values from norms, the results that are closest to the experimental are from EUROCODE: 2004.

4) The fixed values from the norm ABNT NBR 6118: 2014 are lower in approximately $21,6 \%$ in relation to those values obtained experimentally for shear concrete strength. The formula for calculating the portion of shear stress resisted by complementary mechanisms to the truss model $V_{c}=0,6 \cdot f_{c t d} \cdot b_{w} \cdot d$ in simple bending, the multiplying factor of the equation terms can be equal to 0,7296 when considering the results from this research study.

\section{Bibliographic references}

[1] FUSCO, Péricles Brasiliense. Estruturas de concreto: Solicitações Tangenciais. São Paulo: Editora Pini Ltda., 2008. 328 p.

[2] ASSOCIAÇÃO BRASILEIRA DE NORMAS TÉCNICAS. NBR 6118:2014. Projeto de estruturas de concreto - Procedimento. Rio de Janeiro, 2014.

[3] Ritter W. Die bauweise hennebique. Schweizerische Bauzeitung 1899;33:41-61.

[4] ASCE-ACl Committee 445 on Shear and Torsion. Recent approaches to shear design of structural concrete. ASCE, J Struct Eng 1998;124(12):1375-417.

[5] K. De Wilder, P. Lava, D. Debruyne, Y. Wang, G. De Roeck, L. Vandewalle. Experimental investigation on the shear capacity of prestressed concrete beams using digital image correlation.

[6] $\mathrm{ACl}$ Committee 318. 318-11: Building code requirements for structural concrete and commentary. ACl; 2011. p. 503. [3] CEN European Committee for Standardization.
[7] Eurocode 2. Design of concrete structures - general rules and rules for buildings. EN 1992-1-1, Brussels, Belgium; 2004. p. 225.

[8] M. Fernández Ruiz, A. Muttoni, J. Sagaseta. Shear strength of concrete members without transverse reinforcement: A mechanical approach to consistently account for size and strain effects. Engineering Structures, Volume 99 (2015) 360-372.

[9] WALRAVEN, Joost Cornelis. AGGREGATE INTERLOCK: A theoretical and experimental analysis. 1980. $202 \mathrm{f}$. Tese Doutorado - Curso de Engenharia Civil, Delft University Of Technology, Holanda do Sul, 1980.

[10] KIM, Jin-keun; PARK, Yon-dong. Prediction of Shear Strength of Reinforced Concrete Beams without Web Reinforcement. ACl Materials Journal, Estados Unidos, v. 93, n. 3, p.213-222, maio 1996.

[11] Yang Y. Shear behaviour of reinforced concrete members without shear reinforcement, a new look at an old problem. PhD thesis, Delft University of Technology, Delft, Netherlands; 2014. p. 344.

[12] Bentz EC, Vecchio FJ, Collins MP. Simplified modified compression field theory for calculating shear strength of reinforced concrete elements. ACI Struct J 2006;103(4):614-24.

[13] ASSOCIAÇÃO BRASILEIRA DE NORMAS TÉCNICAS. NBR 7222: 1994. Argamassa e concreto - Determinação da resistência à tração por compressão diametral de corpos de prova cilíndricos. Rio de Janeiro, 1994.

[14] AMERICAN CONCRETE INSTITUTE. Building Code Requirements for Structural Concrete (ACI 318-14). Michigan, USA, 2014.

[15] BRITISH STANDARD INSTITUTION, BS 8110 Structural Use of Concrete, Part. 1. Code of Practice for Design and Construction, BSI publications, London, 1997,160 p.

[16] CANADIAN STANDARDS ASSOCIATION. A23.3-04: Design of concrete structures. xviii ed. Ontário: Canadian Standards Association, 2004, 232 p. 
[17] EUROPEAN STANDARD EN 1992-1-1: Eurocode 2: Design of Concrete Structures - Part 1: General rules and rules for buildings, London, 1992.

[18] Fédération Internationale du Béton (fib), Model Code 2010 final draft, vols. 1 and 2, fédération internationale du béton, Bulletins 65 and 66, Lausanne, Switzerland; 2012. p. 350 and p. 370

[19] Samora, M. S. Avaliação dos mecanismos resistentes ao cisalhamento em concreto armado sem armadura transversal. 140 p. Dissertação (Mestrado), Faculdade de Engenharia Civil, Universidade Federal de Uberlândia, 2015.

[20] Ftool - Two-dimensional Frame Analysis Tool: versão 3.0. Luiz Fernando Martha, 2012. Disponível em http://www.tecgraf.puc-rio.br/ftool/. 